\title{
Ecosystem as the Source of Entrepreneurial Opportunities
}

\author{
Julia Trabskaja \\ Research Fellow, trabskaya@gmail.com \\ Tõnis Mets \\ Professor, tonis.mets@ut.ee \\ University of Tartu, Ülikooli 18, 50090 Tartu, Estonia
}

\begin{abstract}
$\mathrm{T}$

he present paper aims to develop an understanding of interconnections between the entrepreneurial ecosystem and entrepreneurial opportunity. The first step of this research was to disclose the development of the ecosystem within two higher (efficiency- and innovationdriven) stages of economic development and the transition between them according to the World Economic Forum, based on the model by Dutch researcher Erik Stam. The Estonian entrepreneurial ecosystem was analyzed as an example. Secondary data on Estonian entrepreneurial ecosystems were collected and analyzed.

In its second step, this research follows a case-study design. The start-up period of the studied Estonian companies represents different degrees of the maturity of the ecosystem: Regio and Mobi Solutions - efficiency-driven, GrabCAD - the transition from efficiency to innovationdriven, and Bolt (Taxify) - an innovation-driven economy.

The example of the Estonian ICT sector proves that the most important contributors to the talent growth, the knowledge base, and framework conditions of the entrepreneurial ecosystem are the state through its infrastructure decisions and educational programs along

with successful entrepreneurs who shape the role models known in Estonia today as the Skype-effect. Decisions on digital telecom infrastructure and e-society in the early stage of the transition in tandem with enterprise encouragement created a subsequent boom in ICT-based ventures in Estonia 10-15 years later. The processes resulted in achieving an innovation-driven society and the highest level of opportunity-driven entrepreneurship in Europe in 2017. With that, new venture funding has replaced the former development engine - foreign direct investment (FDI).

Examples of ICT-based new ventures have demonstrated that the growing maturity of the ecosystem increased venture investment from "bootstrapping" to millions of euros of seed-funding and shortened new product development cycles from 5-7 to 1-3 years. The study shows that maturing ecosystems shorten business development processes, thereby increasing the integration of different ecosystems. The start-up success stories enhance trust in the particular business environment, and they both increase investments and accelerate the entry of new ventures, making better use of the emerging windows of opportunities.
\end{abstract}

Citation: Trabskaja J., Mets T. (2019) Ecosystem as the Source of Entrepreneurial Opportunities. Foresight and STI Governance, vol. 13, no 4, pp. 10-22. DOI: 10.17323/2500identification and transformation; window of opportunity; innovation economy; ICT sector 
$\mathrm{O}$ ne of the roles of the ecosystem's functioning is the creation of a base for the identification of entrepreneurial opportunities. As Shane and Venkataraman [Shane, Venkataraman, 2000, p. 220] assert, "to have entrepreneurship, you must first have entrepreneurial opportunities." However, twenty years after this publication, there still has been no agreement on the most basic questions among scholars. To date, there has been little agreement on how entrepreneurial opportunity and the entrepreneurial ecosystem are interconnected. Researchers [Shane, 2003; Dimov, 2011] argue that opportunities are "born" from fertile soil, develop under the influence of an entrepreneurial ecosystem, and depend upon the entrepreneurial ecosystem's characteristics and idiosyncrasies. However, there are numerous aspects and gaps left mostly ignored on this topic, among them the question of the connection between the evolution of the ecosystem and entrepreneurial opportunity as well as the matching role of a particular window of opportunity.

This paper aims to close this research gap, specifically to develop an approach to understanding the interaction between the ecosystem and the opportunities therein and to further identify connections between the trajectories of the opportunity and the evolutional paths of the ecosystem.

To achieve the aim, the Estonian ICT sector was chosen as the research subject. In a short period of time (since regaining independence in 1991), Estonia has come a long way from a resource-driven ${ }^{1}$ country to an innovation-driven one, from zero innovation (entrepreneurship was banned during the Soviet era) to the creation of a smart economy and a highly developed entrepreneurial ecosystem. This has resulted in the creation of a whole series of global start-ups that, in turn, have reached the status of unicorns. ${ }^{2}$ These developments, including the boom of start-ups in Estonia, were largely due to the introduction of the educational Tiger Leap Program [Mets, 2018], which has led to a focus on human capital and upon the development of competence in the ICT industry.

In order to identify the connection between the ecosystem and opportunity, this paper contains an analysis of the Estonian ecosystem in terms of dynamics and an analysis of the connection between the ecosystem's evolution and the trajectories of opportunity identification (using case studies).

This paper contributes to existing approaches to ecosystems by examining the understanding of an ecosystem's role as an origin of opportunity identification and the transformation process.

\section{From the Entrepreneurial Ecosystem to a Window of Opportunity}

In recent years, there has been increasing interest in entrepreneurial ecosystems among policy makers, researchers [Cohen, 2006; Foster et al., 2013; Isenberg, 2010; Venkataraman, 2004], and international organizations (WEF, OECD, World Bank).

Isenberg [Isenberg, 2011] suggests that in spite of the uniqueness of ecosystems, it is possible to distinguish key elements of ecosystems and arrange them into groups of factors. An entrepreneurial ecosystem is therefore defined "as a system of interrelated pillars that impact the speed and ability with which entrepreneurs can create and scale new ventures in a sustainable way" [WEF, 2014]. Foster et al. [Foster et al., 2013], in further developing Isenberg's ideas, introduced the pillars of an entrepreneurial ecosystem. Stam [Stam, 2015] further developed the ideas of his predecessors [Foster et al., 2013] and suggested a synthetic model. However, the series of factors influencing the development of the ecosystem has not been widely discussed.

First, the proposed models are frequently concentrated on the regional (or national) ecosystem. However, in the modern world, no one entrepreneurial ecosystem can exist in a vacuum and be separate from the global ecosystem. Global processes have an impact upon almost every pillar of the ecosystem - for example, culture (due to the development of technology and the accessibility of information), talents (an open labor market, an education system based upon international student exchange, online courses, etc.) and so on. This is especially typical of the ICT sector, as it is involved in global trends and processes. Companies can belong to different ecosystems, such as having a headquarters (HQ) in one country but working globally [Mets, 2018]. Therefore, we suggest adding the global ecosystem context to the Stam model.

Second, the models fail to disclose the integration of and interactions between different ecosystems. The entrepreneurial ecosystem is comprised of a series of sub-ecosystems, which can be systematized according to the sphere of activity (ecosystems of different sectors, including education). Thus, we suggest studying the interactions between global and local ecosystems as well as sectoral ecosystems.

A group of researchers has addressed the question of the ecosystem's dynamic character. Mason and Brown [Mason, Brown, 2014 p.19] argue that, "much of the discussion of entrepreneurial ecosystems has lacked a time dimension". The entrepreneurial ecosystem

Authors' estimation for the period of 1991-1994.

${ }^{2}$ Unicorn - a start-up valued at 1 billion USD or more. 
evolves and changes its form drastically along the temporal scale, reacting to changing political, economic, and cultural factors.

A dynamic view of the ecosystem is closely connected with the question of path dependence. Is it possible to overcome "the narrow trajectory because of historical experience" [Roundy et al., 2018, p. 5]? Is the ecosystem sensitive to initial conditions? In the next section, we argue that path dependence is not always a necessary attribute of ecosystem evolution.

Researchers who study ecosystems focus on describing and evaluating elements of the ecosystem, indicators of the ecosystem's performance. However, the connection between the ecosystem and the opportunity together with the ecosystem in its capacity as a source of the entrepreneurial opportunity is almost entirely not addressed, although the policies of the governments developing an entrepreneurial ecosystem are directed towards creating better opportunities for entrepreneurs.

Despite the considerable amount of material published on the entrepreneurial opportunity [Alvarez, Barney, 2007; Davidsson, 2015], the nature of this opportunity is still one of the issues of discussion, particularly in the context of ecosystem dynamics and the opportunity window.

Entrepreneurial opportunity is an entrepreneur's ability to undertake an entrepreneurial journey [Mets et al., 2019], to transform an idea into specific results, bring an idea to life and create new value. This topic is replete with debated questions. The nature of the opportunity itself is still vague [Davidsson, 2015; Shane, Venkataraman, 2000; Dimov, 2011]. One of the reasons why research on opportunities is still in the early stages is that the dynamic approach to the opportunity is mostly not addressed. Opportunity is mainly studied at the new venture creation stage. Within the conditions of the rapidly changing market, consumer practices, competitive offers, and a series of other factors, an entrepreneur is constantly forced to redefine opportunities and at times radically transform the product, the developmental trajectory of the company, and the entrepreneurial idea itself. Thus, we can discuss both the identification of the opportunity and the constant and long re-identification of it. Consequently, we examine the development of the ecosystem and the identification of the opportunity in action.

A necessary condition of opportunity identification is the creation or appearance of a window of opportunity. In interpreting the understanding of opportunity as proposed by [Casson, 1982], we suggest that the window of opportunity [Messica, Mehrez, 2002; Suarez et al., 2015] is a collection of situations and conditions that allow for identifying and implementing an opportunity. In other words, an entrepreneurial ecosystem and its pillars together with timing form the window of opportunity. The construct of a window of opportunity is a mechanism that links the trajectory of the opportunity's identification and the entrepreneurial ecosystem. The creation or appearance of a window is one of the most important occurrences in an entrepreneurial ecosystem.

By using the case of Estonia, we have focused on the question of how the ecosystem and the opportunity are connected and how the collection of an ecosystem's pillars form a window of opportunity at a particular stage of economic development.

\section{Methodology}

Our approach is based upon a phase model of economic development [Rostow, 1962], a model of an ecosystem [Stam, 2015], a dynamic view for studying an ecosystem [Mason, Brown, 2014], and upon seeing the opportunity as a phenomenon in a temporal dimension [Dimov, Muñoz, 2015].

In the first part of the empirical section, the analysis of the entrepreneurial ecosystem with examples of Estonian origin start-ups is discussed. The theoretical basis of the empirical part is the ecosystem model developed by [Stam, 2015]. An essential proponents of the study is a dynamic view of the ecosystem. The development of the Estonian ecosystem has been systematized since 1995, as follows, according to the World Economic Forum [WEF, 2014] - the efficiency-driven stage; the transition from the efficiency stage to the innovation-driven stage; and the innovation-driven stage. Estonia is the most successful example of an entrepreneurial ecosystem's development among both the post-Soviet countries and a large part of the former Warsaw Pact [Startup Blink, 2019].

Empirical research is based on data from different sources: official databases, data provided by international organizations (World Economic Forum (Global Competitiveness Index); the World Bank; Eurostat; Global Entrepreneurship Monitor (GEM); Global Entrepreneurship Index (GEI); OECD (Country statistical profiles); Freedomhouse), data provided by Estonian organizations and platforms (Statistics Estonia; Estonian Development Fund; Business Register; Bank of Estonia; Startup Estonia); other secondary data, as well as on the personal knowledge and experience of the authors who have witnessed the transformation of the Estonian ecosystem.

The second part of the empirical section follows a case-study design with an in-depth analysis of the role of the entrepreneurial ecosystem in opportunity identification and transformation processes, and it illustrates the dynamic development of the entrepreneurial ecosystem. The investigated companies have demonstrated different paths and trajectories for development, and they have made various contributions to the entrepreneurial ecosystem of Estonia. 
The study is conducted using mainly ICT-based companies as an example. First, the study of this sphere has practical importance - understanding the laws of development for one of the most rapidly growing sectors, which provides a significant number of innovative ideas to start-ups (including unicorns) and actively changes consumer practices [Venkataraman, 2004]. Second, "the ICT sector was considered the one with the greatest potential" [EDF, 2013], as it contains a significant number of rapidly growing firms and so-called "ambitious entrepreneurs." Many countries today are focused on the support of ambitious entrepreneurs, "policymakers across the OECD are now strongly focused on promoting high growth firms" [Mason, Brown, 2014. p. 2]. It should be noted that in the section devoted to the case studies, we focus specifically on "ambitious entrepreneurs" who are attaining internationalization from inception.

The criteria for selecting cases:

1) the Estonian origin of idea creation;

2)the companies are success stories belonging to the ICT-based sector;

3)the selected companies belong to the 30 start-ups that have raised the most capital;

4) the correspondence of cases to the studied periods of the transformation of the Estonian entrepreneurial ecosystem (each company was established in the corresponding period of the Estonian entrepreneurial ecosystem's development GrabCAD, the late 2000s; Bolt, since 2013-14).

The cases of Regio and Mobi Solutions related to the first period of development for the entrepreneurial ecosystem have not been fully examined since being presented in previous publications [Mets, 2008, 2016]. Some start-ups belonging to the top 30 for investments are not ICT companies, but also briefly analyzed in order to indicate some new trends. The case studies of the start-ups are based mainly on public information from the media, the companies' web pages, the official Commercial Registry databases, and the companies' annual reports. A search for research publications was also carried out using Google Scholar ${ }^{\otimes}$, which helped provide an overview of which aspects of the studied companies researchers have already covered. Personal and public interviews as well as online talks, aside from the published texts, were used to interpret and code the illuminating information in answering the research questions. Start-ups were analyzed in the context of the entrepreneurial process of opportunity development in the entrepreneurial ecosystem framework.

\section{The Entrepreneurial Ecosystem in Dynamics}

Below, general data related to the Estonian entrepreneurial ecosystem in dynamics are presented: the stages are divided according to the WEF (efficiencydriven, transition from efficiency- to innovationdriven, innovation-driven). The structure of the data is based upon the model by Stam [Stam, 2015] in our interpretation (Table 1).

\section{Systemic Conditions}

\section{Networks}

In the 1990s, networking was still being predominantly formed through personal connections. In the 2000s, a whole string of success stories of Estonian origin had a significant influence on forming a positive image of entrepreneurship (e.g., Regio, Skype, Playtech, MicroLink, Delfi). An active network of investors in domestic start-up companies began, for example, Ambient Sound Investments (2003, former Skype developers), supported by the Estonian Development Fund (EDF) state initiative (2006) and a representative office of Enterprise Estonia in Silicon Valley (2007). The early 2010s saw another series of inspiring examples (CrabCad, Transferwise, Pipedrive, etc.) and start-up accelerators were launched, for example, Garage48 (2010) and Wise Guys (2012). Since that period, we can speak in terms of a developed Estonian start-up community integrating personal as well as institutional networks.

\section{Leadership}

In a planned economy, as under the Soviet regime, any private entrepreneurial initiative was suppressed, and a negative attitude towards entrepreneurs was created. In the 1990s, the first generation of entrepreneurs began operating on the market. During this period, it was difficult to talk about innovation project leaders, because innovative projects were rare and did not define the "direction of collective action" [Stam, 2015, p. 4]. In the 2000s and early 2010s, new leaders emerged (former owners - Skype, MicroLink, etc.). Also, it is worth noting the so-called Skype-effect. The success of this company has had a significant impact as a role model for entrepreneurs. In the period since 2014, leadership has shifted to the globally oriented, successful start-up entrepreneurs mentioned above.

\section{Finance}

Since the 1990s, FDI has been promoted by the Estonian government. FDI has targeted industries utilizing comparatively cheap labor. In the 1990s, the primary sources of investment in start-ups were bootstrapping and the Regional Development Agency.

In the 2000s and early 2010s, the development of SMEs was partly supported by European Structural Funds. However, $100 \%$ of the first investments in most growth-oriented start-ups were of Estonian origin ( $€ 5.7$ million in 2006) (Figure 1). The Estonian Development Fund played an essential role in the financial support of start-ups during this period. 
Despite the efforts undertaken, according to a GEDI [GEDI, 2014] assessment, some bottlenecks have been identified in the Estonian entrepreneurial ecosystem. They included finances.

Since 2014, a significant trend has been the growth of annual investments in start-ups, which reached $€ 272.2 \mathrm{M}$ in 2017 and $€ 327.7 \mathrm{M}$ in 2018 . The largest amount is invested in ICT-based start-ups - TransferWise 335.6 million euros, Bolt (Taxify) 152 million euros, AdCash 20 million euros, GrabCAD 11.3 million euros. The fintech company TransferWise received investments of an additional 292 million dollars in May 2019, reaching a value of \$3.5 billion [Härma, 2019].

Of the top 30 investments, only four companies are focused on manufacturing, with two of them combining ICT and software with the production of equipment: Defendec (surveillance technology) and Click \& Grow (hydroponics), and two university R\&D-based energy technology companies, Skeleton and Elcogen. Both energy technology companies have patented technologies that require a long period (over 10 years) of product development and particular production competencies. Skeleton has already moved its production to Germany. This raises the question of whether Estonia is prepared for the appearance of new revolutionary high potential technologies. This is also a question of the professional educational sustainability of the Estonian high-tech industry. To a certain extent, a similar situation exists in the biotech field, where Estonians have been successful in R\&D but have no mainstream industry for the application of their own achievements.

In 2017, about $98 \%$ of investments in Estonian startups were of foreign origin (but it should be mentioned that foreign investments are often made after the movement of the HQ of a start-up company abroad; 20 start-ups that received significant international funding have HQs outside Estonia; two bankrupt firms among the start-ups have HQs in Estonia). The growth in the share of foreign capital in Estonian start-ups, including those with a HQ in Estonia, is an essential indicator of growing trust, and of the integration of local and global ecosystems.

\section{Talent}

The level of the population's education in the 1990s was high: about 30 percent of the population had a higher education. However, there was an acute shortage of entrepreneurial education.

In the 2000s and 2010s, entrepreneurial education became an essential part of higher education for students of all specialities.

In addressing IT education, we have to note that Estonia has had a strong position in this field since the Soviet era. The launch of the Tiger Leap Program in 1996 enabled, inter alia, internet access and computer classes at virtually all schools by the year 2000 . The early period of 2000-2005 saw an increase in the ICT competence of teachers at all levels as well as those of students.

The Study IT in Estonia program operates under the auspices of the government and brings together academic organizations and practitioners in the IT field. In Estonia, the number of ICT students has been steadily increasing and is now over $10 \%$ of the entire student population at the higher education level. Overall, it is possible to talk generally about the integration of entrepreneurial and educational ecosystems.

\section{Knowledge}

Over the years, the education system has been harmonized with the European system. Today, there are several academic and research institutions in Estonia with high positions in the international rankings (Tallinn University of Technology, University of Tartu). Universities are not only a source of knowledge and innovation but also a supplier of talent (the founders of some highly successful companies have emerged from the university environment) and a source of $\mathrm{R} \& \mathrm{D}$-based start-ups.

In 2018, Estonia occupied 21st position for the Quality of Scientific Research Institutions, 17th position for the Quality of Education and 8th position for the Quality of Math and Science Education (among 137 countries) [WEF, 2018]. A warning sign is the lagging R\&D expenses behind strategic goals (see Table 1) and the decline of country's innovativeness according to the European Innovation Scoreboard [European Commission, 2017].
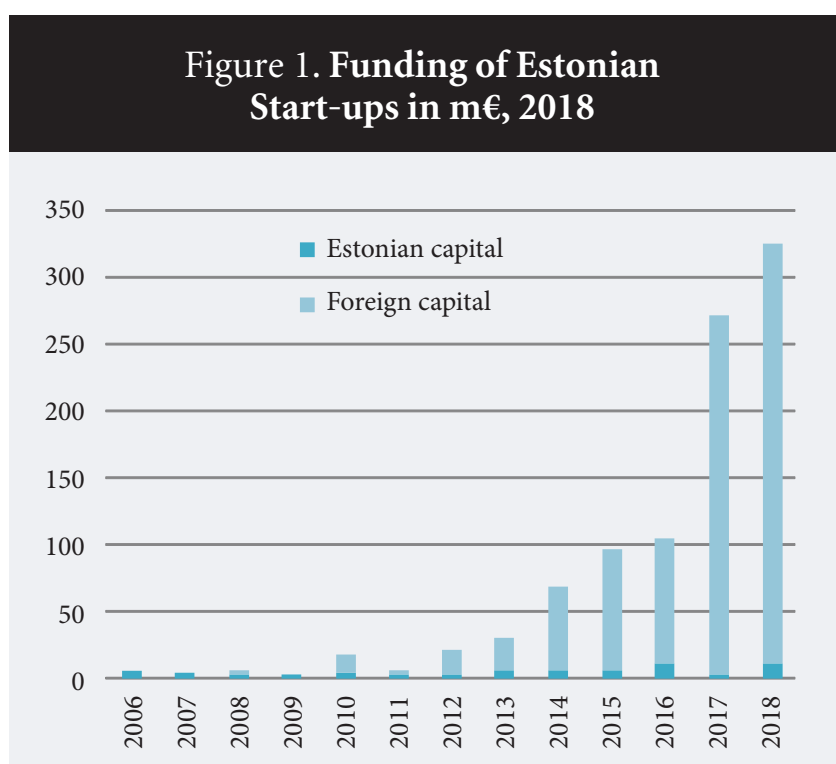

Source: calculated by the authors basing on Garage48.org, 2019. 


\section{Table 1. Evolution of the Estonian Entrepreneurial Ecosystem}

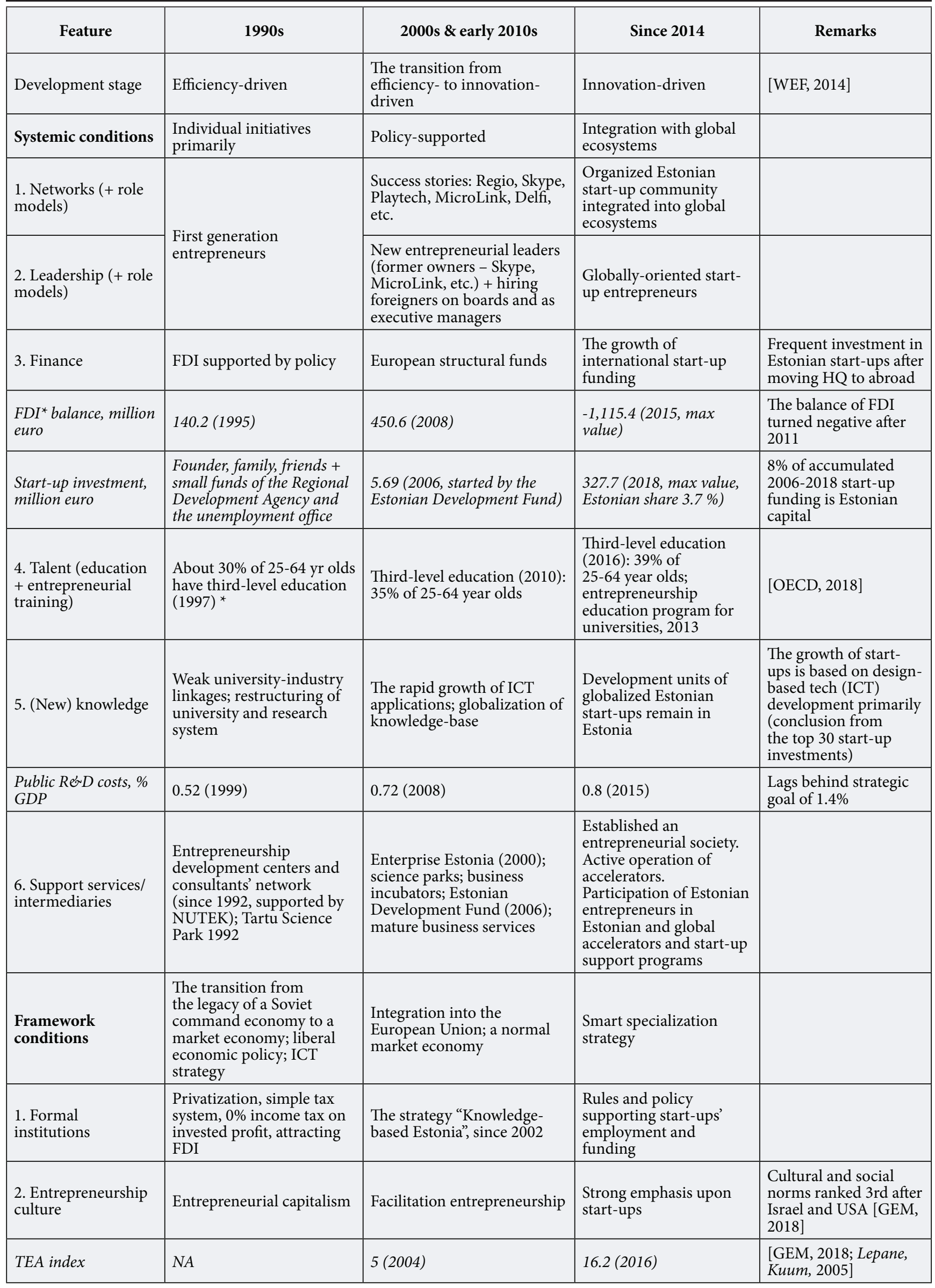


Table 1 continued

\begin{tabular}{|c|c|c|c|c|}
\hline Feature & 1990s & 2000s \& early 2010s & Since 2014 & Remarks \\
\hline $\begin{array}{l}\text { High status to } \\
\text { entrepreneurs*, \% }\end{array}$ & $N A$ & $N A$ & $63.6(2016)$ & [GEM, 2017] \\
\hline $\begin{array}{l}\text { Career choice - } \\
\text { self-employment/ } \\
\text { entrepreneur, \% }\end{array}$ & $N A$ & $28.5(2004)$ & $53.2(2016)$ & $\begin{array}{l}\text { [GEM, 2017; Lepane, } \\
\text { Kuum, 2005] }\end{array}$ \\
\hline $\begin{array}{l}\text { 3. Physical } \\
\text { infrastructure }\end{array}$ & $\begin{array}{l}\text { Poor telecom } \\
\text { infrastructure and roads; } \\
\text { oil shale-based energy } \\
\text { sector }\end{array}$ & $\begin{array}{l}\text { The rapid growth of telecom } \\
\text { networking and the internet; } \\
\text { reconstruction of roads }\end{array}$ & $\begin{array}{l}\text { Ranked 2nd after Hong } \\
\text { Kong [GEM, 2016] }\end{array}$ & \\
\hline 4. Demand & $\begin{array}{l}\text { Small domestic market } \\
\text { with low purchasing } \\
\text { power; fast re-orientation } \\
\text { from the former Soviet } \\
\text { market to the West }\end{array}$ & $\begin{array}{l}\text { Estonia developed into an } \\
\text { export-oriented economy, } \\
\text { exports: } 75 \% \text { of GDP, } 2011\end{array}$ & $\begin{array}{l}\text { The growth of value } \\
\text { added from services } \\
\text { (ICT, building, declining } \\
\text { logistics); services: } 66 \% \\
\text { of GDP and } 33 \% \text { of } \\
\text { exports }\end{array}$ & [Mets, 2018] \\
\hline GDP per capita, euro & 1,935 (1995) & $12,353(2008)$ & $16,476(2016)$ & $\begin{array}{l}\text { Following the crisis, } \\
\text { the } 2008 \text { level was } \\
\text { reached in } 2011\end{array}$ \\
\hline Population, million & 1.437 (1995) & 1.337 (2008) & $1.316(2016)$ & $\begin{array}{l}\text { Trend of emigration } \\
\text { has been partially } \\
\text { replaced by re- } \\
\text { migration since } 2015 \\
\text { [Statistics Estonia, } \\
\text { 2018] }\end{array}$ \\
\hline \multicolumn{5}{|c|}{$\begin{array}{l}\text { * [OECD, 2017], the legacy of the Soviet period mainly ( } 5 \text {-year studies). European educational regulations implemented since the end of the } 1990 \\
\text { ( } 3+\text { years studies). } \\
\text { ** High status - Percentage of the adult population between the ages of } 18 \text { and } 64 \text { years who believe that high status is afforded to successful entrepreneurs } \\
\text { Source: developed by authors. }\end{array}$} \\
\hline
\end{tabular}

\section{Support Services and Intermediaries}

In the 1990s, the development of Estonian support services was backed up by Sweden (NUTEK), Finland, and the European Union (PHARE).

In the 2000s, a group of organizations was established to support entrepreneurial activity, which included Enterprise Estonia (2000) and the Estonian Development Fund (2006). In this period, science parks and business incubators also emerged.

Since 2010, a whole string of organizations have helped establish entrepreneurship and friendly conditions for start-ups (Startup Estonia, SmartCap, Ministry of Economic Affairs and Communications). Incubators also play an active role in cultivating an entrepreneurial mindset - Tartu Science Park (BuildIt), Tallinn Business Incubators, and University of Tartu's Idea Lab.

\section{Framework Conditions}

\section{Formal Institutions}

From the 1990s until now, Estonia has come a long way in developing an entrepreneur-friendly business environment. A low level of corruption and the significant simplification of bureaucratic procedures characterize this environment. In 2017, Estonia was ranked 12th on the Ease of Doing Business Index [World Bank, 2017].

Today, $99 \%$ of public services are available online. Bureaucratic procedures are brought to a minimum. Also, Estonia provides opportunities for foreign residents to start a business in Estonia online - the Startup Visa program (about 21,000 e-residents) [Freedomhouse, 2017].

The WEF [WEF, 2018] has indicated that tax rate regulations are among the most problematic factors for doing business. In the 2014 GEDI report, recommendations for overcoming bottlenecks in the ecosystem were presented. Among the recommendations was to "create tax incentives to encourage business angels and crowdfunding investors" [GEDI, 2014, p. 7].

\section{Entrepreneurial Culture}

The 2000s and early 2010s were marked by facilitation entrepreneurship, the start-up culture became highly developed. The TEA index grew from 5 in 2004 to 16.2 in 2016 . The desire to be an entrepreneur has become more widespread in society (career choice - self-employment/entrepreneur grew from 
$28.5 \%$ (2004) to $53.2 \%$ (2016)) [GEM, 2017; Lepane, Kuนm, 2005].

\section{Physical Infrastructure}

One of the remarkable decisions by the Estonian government was an abandonment of the analogue telecommunication system and giving the telecom concession to a private company AS Eesti Telekom in 1992. In the 2000s, there was rapid development of telecom networking and the internet, as well as the reconstruction of roads with the support of the EU. Among the government's priorities was the development of the ICT sector.

Since 2014, Estonian infrastructure has been ranked second after Hong Kong [GEM, 2016]. More than $99 \%$ of the territory is covered by an internet connection. According to the evaluation of Freedomhouse [Freedomhouse, 2017], Estonia is a model for open internet. Estonia ranks first in the Freedom of the Internet.

\section{Demand and Accessible Markets}

Estonia is a small country (population: 1.4M 1995; $1.3 \mathrm{M} 2008 ; 1.3 \mathrm{M} 2016$ ), and the internal market is small. According to the WEF [WEF, 2018], Estonia ranks 98th of 137 countries for market size estimate. The 1990s were characterized by the low purchasing power of the population (GDP per capita, in 1995 was 1,935 euro). With the combination of these two factors, the country's economic development largely depended and continues to depend upon the openness of the economy. In the 2000s and early 2010s, Estonia was developed into an export-oriented economy (one third of which were services), which comprised $75 \%$ of GDP in 2011. With its entry into the European Union and the harmonization of the economic processes and norms with those of the EU, the global market opened up to Estonian entrepreneurs. The combination of a small domestic market and an open global market led many companies to choose the global development path. The push factors are the need to cover the costs for $\mathrm{R} \& \mathrm{D}$ and limited demand from the domestic market. However, for the ICT sector, it is typical to focus on the global market strategy.

This tendency raises some debate as far as the development of the IT sector in many areas focused on the global market and creates positive effects for the country (hiring of foreign workers, transfer of companies abroad, etc.).

The Estonian experience can be used as an example of how an economy can avoid a typical small market path. Against the backdrop of a limited domestic market, it is imperative for the government to focus on supporting national globally oriented industries.

For a better understanding of the development of an ecosystem, it is important and more illustrative to analyze the development of particular cases. Their paths provide a clear demonstration of principal trends and changes in the entrepreneurial ecosystem as a whole that are reflected in the stories of some IT companies as actors embedded in the entrepreneurial ecosystem.

\section{GrabCAD - a Revolutionary in the Engineering Industry}

Both GrabCAD founders, Hardi Meybaum and Indrek Narusk, were mechanical engineers who founded their engineering services company Futeq in 2007. Indrek Narusk describes the start, as follows: "We ran a small engineering services office back then, and as there was more work coming in than the two of us could handle, we started thinking about how to expand. As everything around us was moving to the web, this seemed like the only option for us too. So, we started building the library as a first step" [Curram, 2011].

Very soon, they had the idea to invite all the engineers into the same virtual space to exchange resources, meet clients and 'grab' CAD designs and models. So, starting from their own needs as engineers, the idea of GrabCAD was born. A three-page business plan was presented to the Estonian Development Fund (EDF) at the end of 2009. Two local investors, Astrec Baltic and EDF, made the first seed investment of $€ 260,000$ into the new body, GrabCAD ${ }^{3}$, in 2010.

The free CAD 3D-model library was launched in September 2010. Engineers could share ready components and products there. This was a step that enabled engineers to cut routine work and focus on unique technical solutions. Further developments took place very rapidly, and although the platform software development remained in Estonia, the headquarters of the (holding) company with its business development unit moved to Boston, USA in 2011. The engineering technology unit was established in Cambridge, UK. These steps were necessary to be near top-level competencies, clients, and funding. GrabCAD won the SeedCamp and TechStars competitions, which enabled it to receive seed investment of $\$ 1.1 \mathrm{M}$ in 2011, followed by $\$ 4 \mathrm{M}$ and $\$ 8.15 \mathrm{M}$ in 2012 . Narusk left the company in 2012.

GrabCAD has become a cloud-based virtual collaboration environment for mechanical engineers and the industry. Workbench was launched in 2013 as an appropriate means for this. Its online community grew

\footnotetext{
${ }^{3}$ See: https://grabcad.com, accessed 10.06.2018.
} 
rapidly from 8,000 engineers in June 2011 to one million users in January 2014. GrabCAD has made it much easier to find team members for engineering projects in the public domain and enabled the collaboration of global teams in private environments. It has shortened new product cycle by two, three, or even more times, linking new ideas to production. The largest customers became General Electric and NASA. In such a way, they created an open innovation platform that breaks the logic of the traditional engineering industry.

In September 2014, it was announced that 3D printing giant Stratasys had acquired GrabCAD, with the value of the deal being around $\$ 100$ million. The investors were happy and the community of users in GrabCAD reached 1.5 million. It was the most outstanding startup sales for Estonians since Skype. Hardi Maybaum stayed on as CEO of the company. His visionary management has led to the most significant change in engineering design in the last 20-30 years. Although he continued to work at the company with the new owner, we do not know if that was a continuation of his entrepreneurial journey. In October 2015, a press release announced that Meybaum had left CrabCAD. It already had 2.5 million members. He started a new job in the Cambridge office of the venture capital company Matrix Partners, USA. Matrix was his advisor on his entrepreneurial journey with GrabCAD.

\section{Bolt - a New Global Giant in the Sharing Economy}

Bolt (earlier: Taxify) was founded on February 7, 2013 and is one of the success stories of Ajujaht (Brain Hunt), an Estonian business idea competition, although it did not in fact win the competition that year (it came in second). However, by June 2013, the Bolt taxi ordering application won a competition for mobile apps in Estonia. Bolt is aimed at consumers and drivers and represents a sharing economy business. ${ }^{4}$

To some extent, Bolt could be considered a "child" of the Estonian start-up community and ecosystem. The initial idea came from Martin Villig, a member of the Skype team from the inception of the company and before its rapid growth [Pashchynska, 2018]. In 2012, he visited Kiev in Ukraine and saw how locals were ordering taxis via a web service [Treija, 2016]. There were no similar services in Tallinn and Riga, which had quite fragmented taxi markets with over 25 taxi companies operating [ibid.].
Martin's younger brother, Markus, who was 19 at the time, applied to found a company under the name mTakso (renamed Taxify in January 2014 and Bolt in 2019) at the Commercial Registry in February 2013. Besides the family members, Oliver Leisalu was also among Bolt's first owners and founders.

In 2014, on receiving recognition for its business concept, Bolt expanded its activities to Finland, Latvia, Lithuania, Belarus, the Netherlands, and Georgia, by which time it had received 1.4 million euros in investor capital. At the end of the year, the company had 14 employees. The circle of shareholders widened with investors of Estonian origin, including Adcash, Mobi Solutions, and Rain Johanson from the former Skype team.

2015 was a year of further (product) development and the growth of sales increased approximately fivefold up to 700,000 euros.

In 2016, the company's growth continued, with sales reaching 2.8 million euros, and cash flow became positive in the last quarter. Bolt also began operating in Africa. Markus Villig, the CEO, was named Young Entrepreneur of the Year.

At the end of 2017, Bolt operated in 30 cities in 23 countries and employed 150 people in Estonia and 350 globally, with subsidiaries in 19 countries, including Australia, Egypt, Kenya, South Africa, Mexico, Canada, the UK, the Netherlands, France, Finland, and others. Sales grew from 2.8 million in 2016 to 18 million euros in 2017 (but it was still not profitable, according to an annual report). Eight months later, it was operating in 47 cities in 27 countries $^{5}$, which means that rapid growth was likely to be expected in 2018 .

The years 2017-2018 also saw more rapid changes and growth. Bolt brought the Chinese (Hong Kong) company Didi Chuxing (a leading IT platform for transport) into the list of shareholders and began strategic collaboration in China (August 1, 2017) ${ }^{6}$. The founders moved the registration of their holding companies from Estonia to Latvia. Daimler Mobility Services $\mathrm{GmbH}$ joined the list of shareholders in May 2018. FORBES named Markus Villig among the 30 most influential young people under 30 in technology in Europe - Technology in $2018^{7}$ [Forbes, 2018].

In May 2018, it was announced that an investment of over 150 million euros was made in the company. Following this round, the value of Bolt became second to TransferWise, and a candidate for fourth position among the so-called 'unicorns' of Estonian origin. With this step, Bolt differed from Estonian start-ups

\footnotetext{
${ }^{4}$ See: Annual reports and data of the Estonian Commercial Registry, 2013-2018. https://www.rik.ee/en/company-registration-portal/annual-report, accessed 25.06.2019.

5 See https://taxify.eu/cities/, accessed 21.06.2019.

${ }^{6}$ See https://geenius.ee/uudis/taxify-sai-investeeringu-ja-alustab-strateegilist-koostood-didi-chuxingiga/, accessed 21.06.2019.

See https://www.forbes.com/profile/markus-villig/?list=30under30-europe-technology\#2bc7db8f1230, ccessed 10.06.2018.
} 
that move their headquarters to global centers (California, Boston, and London) before larger international funding rounds. Bolt remains in Estonia. This is a sign that Estonia has become a global start-up center (as a member of global ecosystem).

\section{Discussion}

This paper aimed to understand the interaction between the ecosystem and the opportunity, and to identify interconnections between the developmental trajectories of the opportunity and evolutionary trajectories of the ecosystem.

We focused on the question of the connection between the ecosystem and the opportunity, and upon which set of pillars of the ecosystem form a window of opportunity at a certain stage of economic development. We consider a window of opportunity to be a combination of particular conditions and situations. An important task was to identify key aspects in the ecosystem (Table 1) that result in the creation of a window of opportunity.

We found that the more an economy is developed, the wider the boundaries of the ecosystem are around the start-up, therefore reaching different ecosystems in both geographical and business senses. The transfer and integration of technological competencies across borders between different ecosystems have a two-way significance in the example of GrabCAD. First, in order to create an engineering crowdsourcing platform, entrepreneurs involve software, mechanical engineering, and design, as well as marketing competencies originating from and dispersed between different geographical regions of Estonia, the UK, and the USA by founding company development branches in these countries. Second, GrabCAD currently integrates more than half of the six million communities of mechanical engineers worldwide, by linking them with potential customers and the production industry in a knowledge and collaboration platform, which takes the form of a kind of new worldwide ecosystem. GrabCAD links engineers and their customers with the industries (producers) worldwide by accelerating team building, project management and any (idea generation, 3D-design, production) collaboration on a common platform. As a result, the productivity of engineers is increasing and the production cycle and market launch of new products are shortening remarkably. All these achievements have already been proven by its major clients: General Electric and NASA. In this way, GrabCAD sourcing a new network - a virtual ecosystem - revolutionizes the entire structure of and the processes used by the engineering industry. Besides using the right opportunity window itself, the platform of GrabCAD became an "opportunity window" for millions of engineers and companies.
Bolt demonstrates how a widespread and seemingly simple mobile-based taxi service can be customized by scaling the technology globally. The product development period was much shorter than that of GrabCAD. However, all the necessary competencies for Bolt, in comparison with GrabCAD, already existed in Estonia and the global investors trusted this ecosystem enough to fund $(€ 152 \mathrm{M})$ the further development of the company with its HQ in Estonia.

The case of GrabCAD also demonstrates the contradictory and dynamic nature of the engineering ecosystem. GrabCAD lost its independence by being acquired by Stratasys for $\$ 100$ million in September 2014. Venture capital investors were happy. GrabCAD, by creating a new collaboration platform for the industry, became the object of an open innovation ecosystem where industry giants deal with innovations. There, one could ask about the happiness of stakeholders, aside from venture capitalists, including those in GrabCAD's homeland. Fostering start-up processes and the concentration of hi-tech start-ups, such as GrabCAD, can be a challenge for the further economic development of Estonia, the country of origin. This raises the question of whether the intensive production of (ideas for) hi-tech startups can be an engine to restructure a traditional country into a 'smart economy'. Also, is an acquisition the best or optimal solution for a hi-tech company such as GrabCAD?

There is no doubt that GrabCAD, in securing international venture funding, channelled this cash flow into the development of competencies and software and relevant employment that has contributed to the socioeconomic welfare of Estonia. International investors forced the faster launch and globalization of the company. The entrepreneurs paid for success by losing control over the business. That was a certain step for them in reaching a competitive advantage. Meybaum later met a man developing a similar platform, but in Spanish, after the sale of GrabCAD. In effect, this means only a slight head start in networking and English language usage facilitated the breakthrough. It also means that aside from the usual 'push-pull' factors of early internationalization, the intensity and speed of the development process appear to be critical in meeting the timing aspect of the opportunity window. The case of GrabCAD is proof of the 'first mover' advantage and that the winner-takes-all in the platform business.

Bolt, in turn, shows that there is an opportunity to establish a challenger in a field with a global competitor as strong as Uber. The speed of development is still a competitive advantage to exploiting a window of opportunity on a massive customer service market that is not yet fully saturated. 
Behind these phenomena is the globally integrated Estonian entrepreneurial ecosystem, which accelerated the whole venture development process for both GrabCAD and Bolt, features that did not exist 10-20 years ago for Mobi Solutions or Regio [Mets, 2016]. The case of GrabCAD also shows how hi-tech startups can implement global networking and knowledge crowdsourcing for their success. Both cases together demonstrate how different interactions and impacts can exist between the entrepreneurial ecosystem and opportunity.

The overview of the Estonian ecosystem generally in dicated that, in addition to the prosperous ICT sector, domestic university R\&D-based high-tech manufacturing is still only in its infancy.

\section{Conclusions}

The development of the Estonian entrepreneurial ecosystem is different from the traditional trajectory completed by the majority of Western European countries. Estonia lacked entrepreneurial traditions, infrastructure, and experience. However, despite this, Estonia has achieved impressive results in a short period of time, partly thanks to joining the European Union (EU) and opening up the Structural Funds, which supported changes. Estonia did start from scratch as did other transition countries and it drastically altered the structure of its industries and infrastructure. Another unique feature is that to create a thriving ecosystem, it did not take a huge amount of investment, rather it required human capital. Therefore, the development trajectory of the Estonian entrepreneurial ecosystem defied the theory of path dependence [Roundy et al., 2018]. In most cases, an ecosystem is sensitive to starting conditions. However, Estonia, despite its historical background, developed a new path (i.e., implementing a wide range of e-services and e-government) and, moreover, skipped several stages (e.g., digital vs analogue telephony, mobile vs cash-machine parking system, etc.) of "traditional" ecosystem evolution in Western countries.

It can be suggested that it is easier in many respects for small economies to overcome path dependence. However, we assume that the most decisive factor for Estonia was not the size of its economy but the political focus on entrepreneurial values, the economic policies of the state and political entrepreneurs who could overcome a short-term perspective and path dependence.

The conducted analysis showed that different stages of an ecosystem's evolution present different entrepreneurial opportunities. Thus, for instance, the speed of an entrepreneurial journey and the speed of the development of a product have changed significantly.

For companies, these developments in the ecosystem mean a drastic shortening of the period of product development. In the 1990s and at the beginning of the 2000s, this period could last 7-10 years, for example, the development periods for Regio or Mobi Solutions [Mets, 2008, 2016] were mainly "bootstrapping" their product development. GrabCAD and Taxify present much faster developments - one to four years with much larger investments accelerating the processes. This characterizes growing competition for exploiting entrepreneurial opportunities. It also means the temporal narrowing of the opportunity window - the ecosystem aspect. However, this is also a sign of the growing maturity of the entrepreneurial ecosystem in Estonia as well as globally.

First, the integration and cooperation of sectoral ecosystems (educational, entrepreneurial, engineering, design, etc.) can be noted. The integration partly succeeded due to the development and introduction of long-term programs for the development of the ecosystem (digital telecom), education (ICT), and entrepreneurial skills at all levels, a long-term vision, and the development of human capital. GrabCAD is proof of the integration trend by the company transforming knowledge from entrepreneurial, educational, engineering, and design ecosystems to the global ecosystems of industries.

Second, the integration of local and global entrepreneurial ecosystems is important. This happened due to Estonia joining international and global organizations that oversee political, trade, security, educational and industrial matters, and introducing western social and economic standards, role models, and open innovations. This helped Estonian companies enter the global market, facilitating a positive image. The examples of GrabCAD and Bolt prove this trend. The companies were initially supported by local ecosystem stakeholders and, as a result, had the opportunity to enter the global market, use global networking, and exploit knowledge.

Third, a growing confidence level manifests itself through increasing foreign investment in general and a share of foreign investment in start-ups specifically. At the beginning of Estonian entrepreneurial ecosystem development, $100 \%$ of investments in Estonian start-ups originated from Estonia. In 2017, the share of foreign investments reached $98 \%$. Also, Estonian start-ups have begun to keep their HQs in Estonia (as in the case of Bolt), instead of moving abroad, which shows that trust is increasing among both foreign investors and entrepreneurs.

Fourth, the formation of an entrepreneurial mindset or the creation of a brand of entrepreneurship in Estonia can be seen. Thus, a very positive image of entrepreneurs has been established, making entrepreneurs the new heroes and role models. Estonia is among the top 15 countries on the Entrepreneurial Spirit Index and one of the places for the most intensive birth of start-ups in the world. 
Fifth, besides the combination and maturity of pillars within the window of opportunity, the timing of all the components of both the entrepreneurial and other ecosystems together is the most important.

Despite the ICT success stories to date, Estonia's challenge is to transform into a knowledge-based economy, to find out how it can develop high-tech manufacturing based on its ideas in the best possible way. This requires the more effective implementation of the R\&D results of universities and the transformation of traditional industry. The prerequisites for this include the better preparation of labor and infrastructure for all sectors and integration with ICT achievements. Currently, public-private collabora- tion and smart decisions by the government in the short term are the most urgent challenges.

In concluding the paper, we assert that a small (post-) transition Estonia with its start-ups demonstrates a solid synchronism of globally oriented new venture creation and entrepreneurial ecosystem development. This enabled the integration of different ecosystems into global networks and the implementation of entrepreneurial opportunities within this framework. The factors behind these enthusiastic processes in a small society have been less studied. Whether the factor is that the phenomenon has a greater ability to mobilize in a small society, the will of independence in a broader meaning, or any other mechanism remains a topic for further studies.

\section{References}

Alvarez A., Barney B. (2007) Discovery and creation: Alternative theories of entrepreneurial action. Strategic Entrepreneurship Journal, vol. 1, pp. 11-26.

Casson M. (1982) The Entrepreneur: An Economic Theory, Oxford: Martin Robertson.

Cohen B. (2006) Sustainable Valley Entrepreneurial Ecosystems. Business Strategy and the Environment, vol. 15, no 1, pp. 1-14.

Curram B. M. (2011) An Interview of GrabCAD's Indrek Narusk. Available at: http://www.draftingservices.com/blog/ aninterviewofgrabcadsindreknarusk, accessed 27.10.2015.

Davidsson P. (2015) Entrepreneurial opportunities and the entrepreneurship nexus: A re-conceptualization. Journal of Business Venturing, vol. 30, no 5, pp. 1-22.

Dimov D. (2011) Grappling with the unbearable elusiveness of entrepreneurial opportunities. Entrepreneurship Theory and Practice, vol. 35, no 1, pp. 57-81.

Dimov D., Muñoz P. (2015) The call of the whole in understanding the development of sustainable ventures. Journal of Business Venturing, vol. 30, no 4, pp. 632-654.

EDF (2013) Smart Specialization - Qualitative Analysis. Available at: http://www.arengufond.ee, accessed 03.06.2019.

European Commission (2017) European Innovation Scoreboard 2017, Brussels: European Commission. Available at: http:// www.eustat.eus/elementos/ele0014400/Methodology_Report_EIS_2017/inf0014422_c.pdf, accessed 10.06.2018.

Foster G., Shimizu C., Ciesinski S., Davila A., Hassan S.Z., Jia N., Plunkett S., Pinelli M., Cunningham J., Hiscock-Croft R., McLenithan M. Rottenberg L., Morris R., Lee D. (2013) Entrepreneurial Ecosystems Around the Globe and Company Growth Dynamics, Geneva: World Economic Forum.

Freedomhouse (2017) Freedom on the Net. Available at: https://freedomhouse.org/report/freedom-net/2017/estonia, accessed 01.05.2019.

GEDI (2014) Towards a More Entrepreneurial Estonia. Call for Action, Washington, D.C.: Global Entrepreneurship and Development Institute.

GEM (2016-2018) Reports of the Global Entrepreneurship Monitor. Available at: www.gemconsortium.org, accessed 31.05.2019.

Härma K. (2019) TransferWise'i väärtus tõusis 3,5 miljardi dollarini: oma osa saavad töötajad ja investorid [The value of TransferWise rose to $\$ 3.5$ billion: employees and investors get their share]. Äripäev [Business Daily], 22.05.2019. Available at: https://www.aripaev.ee/uudised/2019/05/22/transferwisei-vaartus-tousis-35-miljardi-dollarini-oma-osa-saavad-tootajadja-investorid, accessed: 23.06.2019 (in Estonian).

Isenberg D.J. (2010) How to start an entrepreneurial revolution. Harvard Business Review, June, pp. 41-50.

Isenberg D. (2011) The entrepreneurship ecosystem strategy as a new paradigm for economy policy: Principles for cultivating entrepreneurship, Babson Park: MA: Babson College.

Lepane L., Kuum L. (2004) Enterprise of Estonian Population, Tallinn: Estonian Institute of Economic Research (in Estonian).

Mason C., Brown R. (2014) Entrepreneurial ecosystems and growth oriented entrepreneurship (LEED Working Paper), Paris: OECD. Available at: https://www.oecd.org/cfe/leed/Entrepreneurial-ecosystems.pdf, accessed 22.05.2019.

Messica A., Mehrez A. (2002) Time-to-Market, Window of Opportunity, and Salvageability of a New Product Development. Managerial and Decision Economics, vol. 23, pp. 371-378.

Mets T. (2018) Entrepreneurial developments toward a knowledge-based economy in Estonia. The case of Fits.me - venturecapital-backed startup going global. Entrepreneurship in Central and Eastern Europe: Development through Internationalization (eds. T. Mets, A. Sauka, D. Purg), London, New York: Routledge, pp. 89-111. 
Mets T. (2016) Is Estonia becoming better home for 'born globals'? Entrepreneurship, Innovation and Regional Development (eds. D. Smallbone, M. Virtanen, A. Sauka), Cheltenham: Edward Elgar, pp. 101-124.

Mets T. (2008) Regio - a learned global knowledge company: Case from Estonia. The Cutting Edge: Innovation and Entrepreneurship in New Europe (eds. R. Aidis, F. Welter), Cheltenham: Edward Elgar, pp. 54-73.

Mets T., Trabskaja J., Raudsaar M. (2019) The entrepreneurial journey of venture creation: Reshaping process and space. Revista de Estudios Empresariales. Segunda Época, no 1, pp. 61-77.

OECD (2017) Entrepreneurship at a Glance, Paris: OECD. Available at: https://www.oecd-ilibrary.org/employment/ entrepreneurship-at-a-glance-2017_entrepreneur_aag-2017-en, accessed 25.05.2019.

OECD (2018) Country statistical profile: Estonia 2018. Available at: https://www.oecd-ilibrary.org/economics/countrystatistical-profile-estonia-2018-3_csp-est-table-2018-3-en, accessed 25.05.2019.

Pashchynska M. (2018) The Role of Work Experience in The New Business Success in Estonia: The Skype Effect and Beyond (Master's thesis), Tartu: University of Tartu.

Rostow W.W. (1962) The Stages of Economic Growth, London: Cambridge University Press.

Roundy P., Bradshaw M., Brockman B. (2018) The emergence of entrepreneurial ecosystems: A complex adaptive systems approach. Journal of Business Research, vol. 86, pp. 1-10.

Statistics Estonia (2018) Quarterly Bulletin of Statistics Estonia, issue 2, Tallinn: Statistics Estonia. Available at: https://www. stat.ee/publication-download-pdf?publication_id=44735\&publication_lang=en, accessed 21.06.2019.

Shane S. (2003) A General Theory of Entrepreneurship: The Individual-Opportunity Nexus, Cheltenham: Edward Elgar.

Shane S., Venkataraman S. (2000) The Promise of Enterpreneurship as a Field of Research. The Academy of Management Review, vol. 25, no 1, pp. 217-226.

Stam E. (2015) Entrepreneurial Ecosystems and Regional Policy: A Sympathetic Critique. European Planning Studies, vol. 23, no 9, pp. 1759-1769.

Startup Blink (2019) Startup Ecosystem Rankings 2019. Available at: https://www.startupblink.com/blog/startup-ecosystemrankings-report-2019-by-startupblink/, accessed 27.06.2019.

Suarez F., Grodal S., Gotsopoulos S. (2015) Perfect timing? Dominant category, dominant design, and the window of opportunity for firm entry. Strategic Management Journal, vol. 36, pp. 437-448.

Treija I. (2016) Uber, what? Taxify is the most popular taxi startup in the Baltics. Available at: http://www.eu-startups. com/2016/02/uber-what-taxiy-is-the-most-popular-taxi-startup-in-the-baltics/, accessed 22.04.2019.

Venkataraman S. (2004) Regional transformation through technical entrepreneurship. Journal of Business Venturing, vol. 19, pp. $153-167$.

WEF (2014) Global Competitiveness Report 2014-2015, Geneva World Economic Forum.

WEF (2018) Global Competitiveness Report 2018, Geneva: World Economic Forum.

World Bank (2017) World Development Report 2017, Washington, D.C.: World Bank. 